\title{
KINETIC BEHAVIOR OF NITRIFICATION IN THE POST-TREATMENT OF POULTRY WASTEWATER IN A SEQUENTIAL BATCH REACTOR
}

\author{
JULIANA B. R. MEES ${ }^{1}$, SIMONE D. GOMES ${ }^{2}$, MÁRCIO A. VILAS BOAS ${ }^{3}$, \\ BENEDITO M. GOMES ${ }^{4}$, FERNANDO H. PASSIG ${ }^{5}$
}

\begin{abstract}
A sequential batch reactor with suspended biomass and useful volume of $5 \mathrm{~L}$ was used in the removal of nutrients and organic matter in workbench scale under optimal conditions obtained by central composite rotational design (CCRD), with cycle time (CT) of $16 \mathrm{~h}(10.15 \mathrm{~h}$, aerobic phase, and $4.35 \mathrm{~h}$, anoxic phase) and carbon: nitrogen ratio $\left(\mathrm{COD} / \mathrm{NO}_{2}{ }^{-} \mathrm{N}+\mathrm{NO}_{3}{ }^{-}-\mathrm{N}\right)$ equal to 6. Complete cycles (20), nitrification followed by denitrification, were evaluated to investigate the kinetic behavior of degradation of organic (COD) and nitrogenated $\left(\mathrm{NH}_{4}{ }^{+}-\mathrm{N}, \mathrm{NO}_{2}^{-}{ }^{-} \mathrm{N}^{-}\right.$and $\mathrm{NO}_{3}{ }^{-}$ $\mathrm{N})$ matter present in the effluent from a bird slaughterhouse and industrial processing facility, as well as to evaluate the stability of the reactor using Shewhart control charts of individual measures. The results indicate means total inorganic nitrogen $\left(\mathrm{NH}_{4}{ }^{+}-\mathrm{N}+\mathrm{NO}_{2}{ }^{-}-\mathrm{N}+\mathrm{NO}_{3}{ }^{-} \mathrm{N}\right)$ removal of $84.32 \pm 1.59 \%$ and organic matter (COD) of $53.65 \pm 8.48 \%$ in the complete process (nitrificationdenitrification) with the process under statistical control. The nitrifying activity during the aerobic phase estimated from the determination of the kinetic parameters had mean $K_{1}$ and $K_{2}$ values of $0.00381 \pm 0.00043 \mathrm{~min}^{-1}$ and $0.00381 \pm 0.00043 \mathrm{~min}^{-1}$, respectively. The evaluation of the kinetic behavior of the conversion of nitrogen indicated a possible reduction of $\mathrm{CT}$ in the anoxic phase, since removals of $\mathrm{NO}_{2}^{-}-\mathrm{N}$ and $\mathrm{NO}_{3}^{-}-\mathrm{N}$ higher than $90 \%$ were obtained with only $1 \mathrm{~h}$ of denitrification.
\end{abstract}

KEYWORDS: nitrifying activity, kinetic constants, nutrient removal, quality control, processing capacity.

\section{COMPORTAMENTO CINÉTICO DA NITRIFICAÇÃO EM UM REATOR EM BATELADAS SEQUENCIAIS USADO NO PÓS-TRATAMENTO DE EFLUENTE AVÍCOLA}

RESUMO: Um reator em bateladas sequenciais com biomassa em suspensão e volume útil de 5L, aplicado para remoção de nutrientes e matéria orgânica, foi operado em escala de bancada, nas condições ótimas obtidas a partir de um delineamento composto central rotacional (DCCR), tempo de ciclo (TC) de $16 \mathrm{~h}$ (10h15 fase aeróbia e $4 \mathrm{~h} 35$ fase anóxica) e relação carbono:nitrogênio (DQO/N-NO ${ }_{2}^{-}$ $\left.+\mathrm{N}^{-\mathrm{NO}_{3}}{ }^{-}\right)$de 6. Avaliaram-se 20 ciclos completos, nitrificação seguida de desnitrificação, com o objetivo de efetuar o estudo do comportamento cinético de degradação da matéria orgânica (DQO) e nitrogenada $\left(\mathrm{N}_{-} \mathrm{NH}_{4}{ }^{+}, \mathrm{N}_{-} \mathrm{NO}_{2}{ }^{-}\right.$e N-NO$\left.{ }_{3}{ }^{-}\right)$presentes no efluente proveniente do abate e industrialização de aves, bem como avaliar a estabilidade do reator através de gráficos de controle Shewhart para medidas individuais. Os resultados apontaram valores médios de remoção de nitrogênio inorgânico total $\left(\mathrm{N}-\mathrm{NH}_{4}{ }^{+}+\mathrm{N}-\mathrm{NO}_{2}{ }^{-}+\mathrm{N}-\mathrm{NO}_{3}{ }^{-}\right)$de $84,32 \pm 1,59 \%$ (C.V.=1,89\%) e de matéria orgânica (DQO) de $53,65 \pm 8,48 \%$ ( $C V=15,81 \%)$, no processo completo (nitrificação-desnitrificação), estando o processo sob controle estatístico. A atividade nitrificante estimada, durante a fase aeróbia, pela determinação dos parâmetros cinéticos, apresentou valores médios para $\mathrm{K}_{1}$ e $\mathrm{K}_{2}$, de $0,00381 \pm 0,00043 \min ^{-1}$ e $0,00249 \pm 0,00056 \mathrm{~min}^{-1}$, respectivamente. A avaliação do comportamento cinético de conversão do nitrogênio indicou possível redução no TC da fase anóxica, uma vez que foram alcançadas remoções de $\mathrm{N}-\mathrm{NO}_{2}{ }^{-}$e $\mathrm{N}_{-\mathrm{NO}_{3}}^{-}$, superiores a $90 \%$, em apenas uma hora de desnitrificação.

PLAVRAS-CHAVE: atividade nitrificante, constantes cinéticas, remoção de nutrientes, controle de qualidade, capacidade de processo.

\footnotetext{
${ }^{1}$ Profa. Doutora, UTFPR/Medianeira, juliana@utfpr.edu.br.

${ }^{2}$ Profa. Associada, CCET - Universidade Estadual do Oeste do Paraná (UNIOESTE), Cascavel - PR, simone.gomes@unioeste.br.

${ }^{3}$ Prof. Associado, CCET- Universidade Estadual do Oeste do Paraná (UNIOESTE), Cascavel - PR, marcio.vilasboas@ unioeste.br

${ }^{4}$ Prof. Associado, CCET- Universidade Estadual do Oeste do Paraná (UNIOESTE), Cascavel - PR, benedito.gomes@ unioeste.br.

${ }^{5}$ Eng $^{\mathrm{o}}$ Sanitarista, Prof. Doutor, Coordenação de Eng ${ }^{\mathrm{a}}$ Ambiental, UTFPR-CM, Campo Mourão - PR, fhpassig@utfpr.edu.br.

Recebido pelo Conselho Editorial em: 22-5-2010
}

Aprovado pelo Conselho Editorial em: 29-5-2011 


\section{INTRODUCTION}

Nitrogen occurs as many compounds due to its various oxidation states, allied to the fact that many changes can be provoked by living organisms. In the environment, nitrogen is found more frequently as ammonia $\left(\mathrm{NH}_{3}\right)$, ammonium ion $\left(\mathrm{NH}_{4}{ }^{+}\right)$, nitrate $\left(\mathrm{NO}_{3}{ }^{-}\right)$, or gaseous nitrogen $\left(\mathrm{N}_{2}\right)$. The ammonia-ammonium equilibrium equation is $\mathrm{NH}_{4}{ }^{+} \leftrightarrow \mathrm{NH}_{3}+\mathrm{H}^{+}$. According to WIESMANN et al. (2007), for acid $\mathrm{pH}$ values, the concentration of $\mathrm{H}^{+}$increases and at $\mathrm{pH}$ below 7, ion ammonium predominates. At basic $\mathrm{pH}$, the concentration of $\mathrm{H}^{+}$decreases and at $\mathrm{pH}$ over 11, practically all ammoniacal nitrogen occurs as gaseous ammonia.

Traditionally, the elimination of nitrogen from wastewaters is performed by biological processes involving nitrification followed by denitrification. In nitrification, according to LI \& IRVIN (2007), ammonia or ammonium ion is oxidized to nitrite by ammonia oxidizing autotrophic bacteria, during nitritification; next, nitrite is oxidized to nitrate during nitratification. During denitrification, nitrate is converted to gaseous nitrogen, with nitric oxide (NO) and nitrous oxide as possible intermediates $\left(\mathrm{N}_{2} \mathrm{O}\right)$. According to JULIASTUTI et al. (2003), nitrification is the most sensitive process among the processes of biological removal of nutrients from residual waters. The autotrophic mass is approximately 10-fold more sensitive than the heterotrophic biomass.

The nitrifying process is carried out by two groups of bacteria. The first group belongs mainly to the Nitrosomonas genus, being responsible for nitritation, and the second group, responsible for nitration, belongs mainly to the Nitrobacter genus (HAMMER \& HAMMER, 2007). According to GRUNDITZ \& DALHAMMAR (2001), because the bacteria responsible for nitrification are limited to a few genera with slow cell growth, this process is more susceptible to inhibition.

Biochemically, the nitrification process involves more than the sequential oxidation of $\mathrm{NH}_{4}^{+} / \mathrm{NH}_{3}$ to $\mathrm{NH}_{4}^{+} / \mathrm{NH}_{3}$ by Nitrosomonas and $\mathrm{NO}_{2}^{-}$to $\mathrm{NH}_{4}^{+} / \mathrm{NH}_{3}$ by Nitrobacter. Several intermediate reactions, enzymes, and coenzymes are involved in the process (GRADY et al., 1999). Furthermore, the responses of the nitrifying bacteria to a series of factors, such as temperature, $\mathrm{pH}$, oxygen concentration, and substrate concentration, must be considered (FONTENOT et al., 2007; SEIXO et al., 2004). This information is important for the design of nitrification systems and to ensure that the nitrifying microorganisms are capable of presenting efficient metabolic activity (FERREIRA, 2000). Knowledge of the kinetics of the nitrification and denitrification reactions is essential for the design of reactors for the removal of nutrients from wastewaters, and so is the choice of the type of process to be used, its particularities, and treatment characteristics.

The kinetic study of reactors, such as sequential batch reactors (SBR) can be done based on the velocity of growth of the microorganisms, the consumption of the substrate, and the formation of products, or by relating all these intrinsically related factors.

To evaluate the stability of the processes, MONTGOMERY (2004) suggests the use of statistical control of quality to identify the problem points that hinder the process, in addition to evaluate the behavior of the variability of the process. The variability can be controlled by means of statistical tools, such as the Shewhart control charts for individual measures (WERKEMA, 1995).

This research aimed to investigate the kinetic behavior of degradation of carbonaceous organic matter and nitrogenated matter present in the wastewater from a bird slaughterhouse and processing industrial facility using an SBR and to evaluate the stability of the reactor using Shewhart control charts for individual measures, and the kinetic profile of nitrification by calculating the apparent kinetic constants $\mathrm{K}_{1}$ and $\mathrm{K}_{2}$.

\section{MATERIAL AND METHODS}

\section{Sequential batch reactor and operating conditions}

The experimental study was performed in workbench scale in the Medianeira campus of the Federal Technological University of Paraná, UTFPR. The 5-L working volume sequential batch 
reactor (SBR) was constructed using a polyethylene cylinder. The substrate used was wastewater from a bird slaughterhouse and processing facility and cassava wastewater from a cassava meal company. Initially, the reactor was inoculated with active sludge with a volatile solids suspended (VSS) concentration of $2000 \mathrm{mg} . \mathrm{L}^{-1}$ from another SBR. The system was kept in an acclimatized room at $25^{\circ} \mathrm{C}\left( \pm 1^{\circ} \mathrm{C}\right)$, operating in cycles of loading, reaction (aerobic/anoxic), sedimentation, unloading, rest.

In the aerobic phase, air was supplied by using air stones and a Big-Air pump, model A-420, coupled to a flow meter for control of the air flow, set at $3 \mathrm{~L} \cdot \mathrm{min}^{-1}$ for an effluent volume of $5 \mathrm{~L}$. The alkalinity and $\mathrm{pH}$ were initially corrected in this phase with sodium bicarbonate at the proportion of $0.61 \mathrm{mg} \mathrm{NaHCO} 3$ per mg of oxidized $\mathrm{NH}_{4}{ }^{+}-\mathrm{N}$ (JANG et al., 2004). A mechanical agitator running at $25 \mathrm{rpm}$ was used in the anoxic phase.

During the cycles, the concentration of volatile suspended solids dispersed in the liquid mass of the reactor (MLSSV) was kept at $2600.07 \pm 6.84 \mathrm{mg} \mathrm{L}^{-1}$. The dispersed MLSSV concentration was fitted with a methodology based on optical density, which was determined with a 700-nm spectrophotometer and with periodical sludge unloading at the end of each batch. A volume of $1.25 \mathrm{~L}$ of sludge was left in the reactor as an inoculant for the following stages, after the sedimentation and unloading stages.

\section{Analysis of the stability of the reactor with Shewhart control charts for individual measures}

The process of biological removal of nutrients from the effluent from a bird processing slaughterhouse was optimized using a star-type $\left(\alpha=45^{\circ}\right)$ central composite rotational design (CCRD) that comprised a factorial design $\left(2^{2}\right)$ with levels $(-1$ and +1$)$, axial points $(-\sqrt{2}$ and $\sqrt{2})$, and five repetitions at the central point (0), giving the optimal condition with cycle time (CT) of $16 \mathrm{~h}$ and $\mathrm{C} / \mathrm{N}$ ratio of 6.

Data were collected in 20 16-h cycles of treatment (960 min) using instantaneous loading and $\mathrm{CT}$ of $10.15 \mathrm{~h}(610 \mathrm{~min})$ for the aerobic phase, $4.35 \mathrm{~h}(260 \mathrm{~min})$ for the anoxic phase, $1 \mathrm{~h}(60 \mathrm{~min})$ for the sedimentation phase, $0.1 \mathrm{~h}(6 \mathrm{~min})$ for the unloading phase, and $0.4 \mathrm{~h}(24 \mathrm{~min})$ for the rest phase. The carbon:nitrogen ratio $\left(\mathrm{COD} / \mathrm{NO}_{2}{ }^{-} \mathrm{N}+\mathrm{NO}_{3}{ }^{-} \mathrm{N}\right)$ was fitted to 6 in the beginning of the anoxic phase by adding $560 \mathrm{~mL}$ of cassava wastewater with a COD of $6581.25 \pm 569.66 \mathrm{~mL}$.

The stability of the process was evaluated through the removal of total inorganic nitrogen $\left(\mathrm{NH}_{4}{ }^{+}-\mathrm{N}+\mathrm{NO}_{2}{ }^{-} \mathrm{N}+\mathrm{NO}_{3}{ }^{-} \mathrm{N}\right)$ and of organic matter (COD) in the complete process (nitrificationdenitrification). Evaluation was carried out with the Shewhart control charts for individual measures and software MINITAB 15.0 and the mean values and amplitude obtained in the 20 assays that were preformed. The lower control limit (LCL), the upper control limit (UCL), and the mean line $(\bar{X})$ were calculated for plotting the graphs with the methodology cited by MONTGOMERY (2004).

\section{Kinetics of removal of organic matter and nitrogen conversion}

During the 16-h assays for the estimation of organic matter consumption and nitrogen conversion in the SBR, samples were collected every hour with an $80-\mathrm{mL}$ syringe. The samples were centrifuged at $5000 \mathrm{rpm}$ for $10 \mathrm{~min}$ (FONTENOT et al., 2007) to determine the chemical demand of oxygen (COD) and the forms of nitrogen $\mathrm{NH}_{4}{ }^{+}-\mathrm{N}, \mathrm{NO}_{2}{ }^{-} \mathrm{N}$, and $\mathrm{NO}_{3}{ }^{-}-\mathrm{N}$. Besides these parameters, the $\mathrm{pH}$, redox potential, the salinity and the temperature were also monitored.

The procedures described in the Standard Methods (APHA, 1998) were followed for total ammoniacal nitrogen (Method 4500F) and the chemical demand of oxygen (Method 5220D). Nitrate and nitrite were analyzed, respectively, by the cadmium and ferrous sulfate methods using Hach kits for analysis of water and effluent (Hach, DR 2010). The pH, redox potential, salinity, and temperature were measured with a multiparameter probe (model HI 769828, Hanna Instruments). 


\section{Determination of the nitrifying activity}

The conversion of ammoniacal nitrogen to nitrite and nitrate was determined by first-order kinetic reaction in series with a single intermediate, according to the model described by LEVENSPIEL (2000) [ammoniacal $-N] \stackrel{k_{1}}{\longrightarrow}\left[\mathrm{NO}_{2}^{-}-N\right] \stackrel{k_{2}}{\longrightarrow}\left[\mathrm{NO}_{3}^{-}-N\right]$, based on the hypothesis that inorganic carbon and oxygen are in excess and nitrogen is the only limiting factor.

The nitrifying activity was estimated by determining the kinetic parameters $K_{1}$ and $K_{2}$, based on the fitting of the kinetic models represented by the equations of consumption of the substrate $\mathrm{N}$ $\mathrm{NH}_{4}{ }^{+}$(Eq. 2) as a function of the production of the oxidized forms $\left(\mathrm{NO}_{2}^{-}-\mathrm{N}\right.$ and $\left.\mathrm{NO}_{3}{ }^{-} \mathrm{N}\right)$ in the nitrification stages (Eq. 3) and nitratation (Eq. 4).

$$
\begin{aligned}
& {[\text { ammoniacal }-N]=[\text { ammoniacal }-N]_{0} \cdot e^{-k_{1} \cdot t}} \\
& {\left[N O_{2}^{-}-N\right]=[\text { ammoniacal }-N]_{0} \cdot k_{1}\left(\frac{e^{-k_{1} \cdot t}}{k_{2}-k_{1}}+\frac{e^{-k_{2} \cdot t}}{k_{1}-k_{2}}\right)} \\
& {\left[\mathrm{NO}_{3}^{-}-N\right]=[\text { ammoniacal }-N]_{0} \cdot k_{1}\left(1+\frac{k_{2}}{k_{1}-k_{2}} e^{-k_{1} \cdot t}+\frac{k_{1}}{k_{2}-k_{1}} e^{-k_{2} \cdot t}\right)}
\end{aligned}
$$

\section{RESULTS AND DISCUSSION}

\section{Characterization of the effluent treated in the studied SBR}

Table 1 presents the results of organic matter consumption evaluated by the COD and the removal of nitrogen evaluated by determination of the forms of nitrogen $\mathrm{NH}_{4}{ }^{+}-\mathrm{N}, \mathrm{NO}_{2}{ }^{-}-\mathrm{N}$, and $\mathrm{NO}_{3}{ }^{-} \mathrm{N}$, as well as the mean values obtained for the other monitored parameters during the experimental procedure, $\mathrm{pH}$, temperature, redox potential, and salinity.

TABLE 1. Mean results obtained for the monitored parameters during the experimental procedure.

\begin{tabular}{lcccc}
\hline Variable & $\begin{array}{c}\text { Affluent Aerobic } \\
\text { Phase }\end{array}$ & $\begin{array}{c}\text { Effluent Aerobic } \\
\text { Phase }\end{array}$ & $\begin{array}{c}\text { Affluent Anoxic } \\
\text { Phase }\end{array}$ & $\begin{array}{c}\text { Effluent Anoxic } \\
\text { Phase }\end{array}$ \\
\hline $\mathrm{NH}_{4}{ }^{-}-\mathrm{N}\left(\mathrm{mg} \mathrm{L}^{-1}\right)$ & $133.26 \pm 8.99$ & $10.87 \pm 2.07$ & $12.23 \pm 2.08$ & $10.45 \pm 1.96$ \\
$\mathrm{NO}_{2}^{-}-\mathrm{N}\left(\mathrm{mg} \mathrm{L}^{-1}\right)$ & $5.90 \pm 2.00$ & $57.00 \pm 9.38$ & $47.00 \pm 9.65$ & $4.95 \pm 0.60$ \\
$\mathrm{NO}_{3}^{-}-\mathrm{N}\left(\mathrm{mg} \mathrm{L}^{-1}\right)$ & $11.80 \pm 3.65$ & $178.03 \pm 28.24$ & $137.50 \pm 26.23$ & $8.21 \pm 1.06$ \\
$\mathrm{COD}\left(\mathrm{mg} \mathrm{L}^{-1}\right)$ & $297.69 \pm 36.00$ & $154.44 \pm 24.60$ & $1115.12 \pm 191.69$ & $136.56 \pm 21.65$ \\
$\mathrm{pH}$ & $7.23 \pm 0.19^{*}$ & $6.83 \pm 0.33$ & $5.82 \pm 0.64 *$ & $7.61 \pm 0.12$ \\
Redox Potential $(\mathrm{mV})$ & $-132.73 \pm 15.97$ & $99.33 \pm 23.78$ & $218.38 \pm 27.36$ & $-59.77 \pm 18.61$ \\
Salinity $(\%)$ & $0.65 \pm 0.04$ & $0.43 \pm 0.04$ & $0.42 \pm 0.03$ & $0.37 \pm 0.03$ \\
Temperature $\left({ }^{\circ} \mathrm{C}\right)$ & $22.75 \pm 1.68$ & $26.35 \pm 1.18$ & $24.91 \pm 1.12$ & $26.59 \pm 1.04$ \\
Carbon: Nitrogen ratio & $2.24 \pm 0.32$ & - & $6.05 \pm 0.16$ & - \\
\hline Tron
\end{tabular}

Arithmetical means of $2016-\mathrm{h}$ cycles \pm standard deviation.*Uncorrected $\mathrm{pH}$ values, later correction kept $\mathrm{pH}$ in the range 7.5-8.0 in the aerobic phase (nitrification) and at approximately 6.5 in the anoxic phase (denitrification).

From the results in Table 1, it can be conclude that the efficiency of removal of $\mathrm{NH}_{4}{ }^{+}-\mathrm{N}$ during the nitrification stage varied from $89.51 \%$ to $93.71 \%$, with a mean value of removal of $91.85 \pm 1.50 \%$ for $\mathrm{CT}$ of $10.15 \mathrm{~h}$ in the aerobic phase.

SEIXO et al. (2004) used an SBR to treat synthetic effluent and obtained a removal value lower than the present value of $69.8 \%$ obtained for a Corg/ $\mathrm{N}$ ratio adjusted to 3 ; however, the $\mathrm{CT}$, $9 \mathrm{~h}$, was shorter in the aerobic phase.

The $\mathrm{C} / \mathrm{N}$ ratio $\left(\mathrm{COD} / \mathrm{NH}_{4}{ }^{+}-\mathrm{N}\right)$ remained at $2.24 \pm 0.32$ in the beginning of the nitrification stage. In the nitrification processes, according to METCALF \& EDDY (2003), for the good performance of the nitrifying bacteria, this ratio must be lower than 3 . 
Likewise, CARVALLO et al. (2002), found removal rates of $\mathrm{NH}_{4}{ }^{+}-\mathrm{N}$ of 65 and $99 \%$ for different values of COD/NTK ratios between 1 and 8. For COD/NTK ratios lower than 3, they obtained an $\mathrm{N}^{-\mathrm{NH}_{4}}{ }^{+}$removal value of $99.4 \%$.

The effect of the $\mathrm{C} / \mathrm{N}$ ratio, in which the carbon is the biodegradable fraction of the organic load, is one of the factors that affect the nitrification systems (FERREIRA, 2000). High concentrations of organic matter afford favorable conditions for the development of heterotrophic microorganisms, which compete with the autotrophic nitrifying organisms for oxygen and nutrients (FIGUEROA \& SILVERSTEIN, 1992).

ANDRADE et al. (2010) evaluated the factors air flow and concentration of ammoniacal $\mathrm{N}$ in the nitrification of the effluent of a fish processing plant using SBR with HRT of $24 \mathrm{~h}$, and concluded through monitoring of nitrogen forms that $16 \mathrm{~h}$ was sufficient for nitrification to occur in the best conditions that were evaluated.

The efficiency of removal of $\mathrm{NO}_{2}{ }^{-}-\mathrm{N}$ and $\mathrm{NO}_{3}{ }^{-} \mathrm{N}$ in the denitrification stage had mean values of $88.93 \pm 3.09 \%$ and $93 \pm 3.09 \%$, respectively, for the $\mathrm{C} / \mathrm{N}$ ratio of $6.05( \pm 0.16)$ and a $\mathrm{CT}$ of $4.35 \mathrm{~h}$ in the anoxic phase.

KUMMER (2008) used cassava wastewater as a carbon source in the denitrification of the effluent of a fish processing facility in an SBR with CT of $24 \mathrm{~h}$. Tests of different $\mathrm{COD} / \mathrm{NO}_{3}{ }^{-}$ $(0.1 ; 1.0 ; 3.2 ; 5.4$ and 6.3) gave mean nitrite and nitrate removal rates of $66.7 \%$ and $85.6 \%$, respectively, for a $\mathrm{COD} / \mathrm{NO}_{3}{ }^{-}$of 6.3 .

The removal of total inorganic nitrogen $\left(\mathrm{NH}_{4}{ }^{+}-\mathrm{N}+\mathrm{NO}_{2}{ }^{-} \mathrm{N}+\mathrm{NO}_{3}{ }^{-} \mathrm{N}\right)$ in the complete cycle treatment (nitrification-denitrification) with CT of $16 \mathrm{~h}$ ranged from $81.05 \%$ to $87.29 \%$.

During the essays, parameters such as temperature, $\mathrm{pH}$, redox potential, and salinity, were also monitored, because they can influence the nitrification and denitrification processes.

The temperature of the wastewater in the reactor during the treatment cycles ranged from $22.75 \pm 1.68$ to $226.59 \pm 1.04{ }^{\circ} \mathrm{C}$, which favored the development of the nitrifying microorganisms. According to BAE et al. (2002), the optimum temperature for the growth of nitrifying microorganisms ranges from 30 to $35^{\circ} \mathrm{C}$. However, investigation of the treatment of shrimp aquaculture effluent by FONTENOT et al. (2007) using an SBR at different temperatures (22; 28; 37 and $45^{\circ} \mathrm{C}$ ) showed a similar performance for a wide range of temperatures, $22-37^{\circ} \mathrm{C}$, and reductions over $89 \%$ of all species of nitrogen evaluated (nitrite, nitrate, and ammoniacal nitrogen). High temperatures result in a high consumption of oxygen and high alkalinity, which are necessary for nitrification; in contrast, low temperatures reduce the nitrifying activity.

In relation to the $\mathrm{pH}$, according to WIESMANN et al. (2007), the microorganisms responsible for nitrification develop better in slightly alkaline conditions, in the range from 7.2 to 8.0. To obtain these conditions, the $\mathrm{pH}$ was adjusted in the beginning of the aerobic phase to values between 7.5 and 8.0. According to FERREIRA (2000), the nitrification rate can drop significantly for $\mathrm{pH}$ value below the neutral zone. The recommended $\mathrm{pH}$ value for the nitrification process is in the range 6.58.0 .

It can be seen in Table 1 that the effluent of the aerobic phase presented a mean $\mathrm{pH}$ value of $6.83 \pm 0.33$, which is a consequence of the consumption of the alkalinity in the nitrification stage. Relative to the redox potential (ORP), it was observed an increase in the aerobic phase (nitrification), reaching a mean value of $99.33 \pm 23.78 \mathrm{mV}$, which is close to the optimum value recommended by WANNER (1991) for nitrification, 100-300 mV.

In the anoxic phase, the reduction in the ORP was pronounced, reaching a mean value of $59.77 \pm 18.61 \mathrm{mV}$. AKIN \& UGURLU (2005) observed that the best ORP used as an indicator in the end of the anoxic period was $-55.0 \mathrm{mV}$. WANNER (1991) found that the optimum ORP for the denitrification is from -50.0 to $50.0 \mathrm{mV}$. 
The initial concentration of salts was lower than $0.7 \%$ for all the treatment cycles. Studies by UYGUR \& KARGI (2004) evaluated the influence of salinit6y (0-6\%) on the reduction of nutrients in synthetic effluent treated in an SBR. It was observed that the removal rate of $\mathrm{NH}_{4}{ }^{+}$was not significantly affected by saline concentrations below $1 \%$, attaining removal percentages over $80 \%$. The percent removal of $\mathrm{NH}_{4}{ }^{+}$decreased sharply, from 96 to 39\%, when the saline concentration ranged from 0 to $6 \%$, a reduction of over $50 \%$.

GROMMEN et al. (2005) reported that salinity is known to decrease the diversity of the nitrifying microorganism population.

\section{Analysis of the stability of the reactor}

Figure 1 shows the Shewhart control chart for individual measures of removal of total inorganic nitrogen over 20 assays.

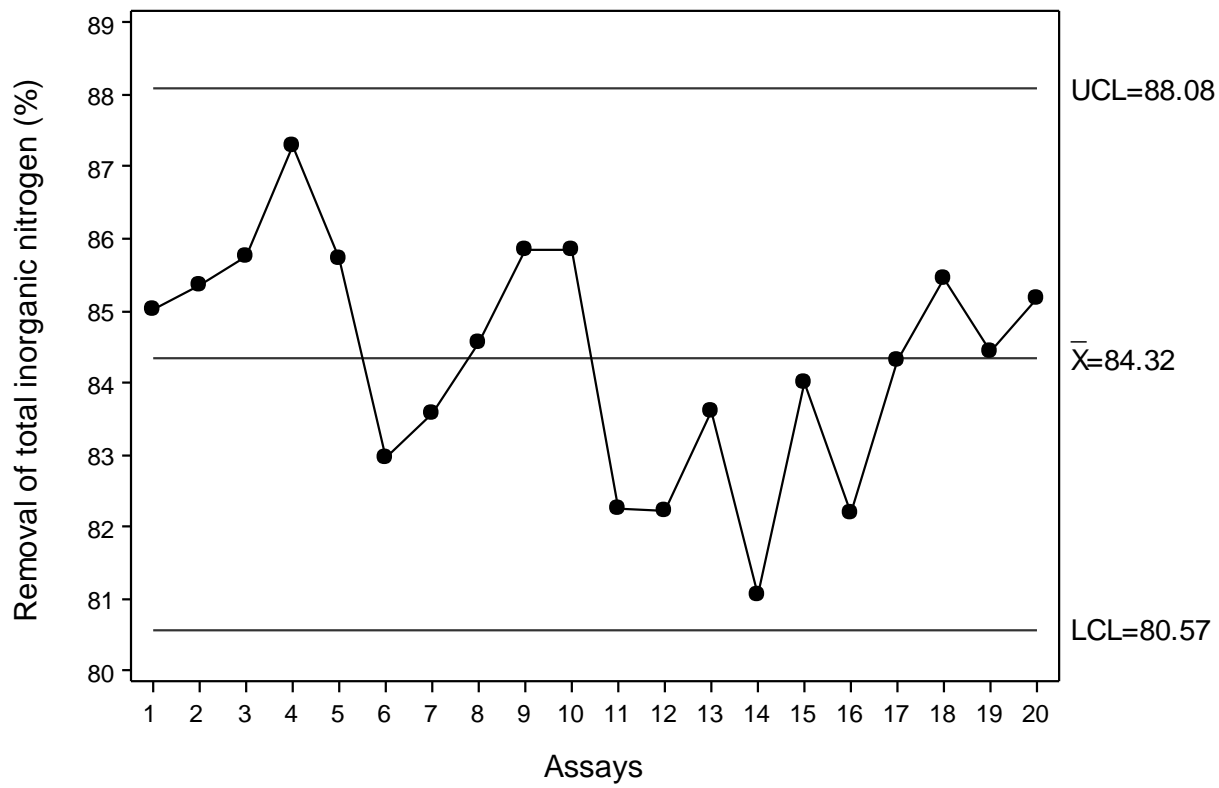

FIGURE 1. Shewhart control chart of individual measures for the removal of total inorganic nitrogen $\left(\mathrm{NH}_{4}^{+}-\mathrm{N}+\mathrm{NO}_{2}^{-}-\mathrm{N}+\mathrm{NO}_{3}{ }^{-} \mathrm{N}\right)$ in the complete process (nitrificationdenitrification).

In Figure 1, one can see that the efficiency of global removal of inorganic nitrogen had a mean value of $84.32 \pm 1.59 \%$ with a coefficient of variation $(\mathrm{CV})$ of $1.89 \%$, which was confirmed by the reproducibility of the biological treatment process, determined by the low coefficient of variation, which indicates the homogeneity of the experimental data obtained. The lower control limit (LCL) was $80.57 \%$ and the upper control limit (UCL) was $88.08 \%$, without any point outside the limits. This fact indicates that the results are statistically satisfactory and that the process is under statistical control.

Figure 2 gives the Shewhart control chart of individual measures for the removal of CDO. 


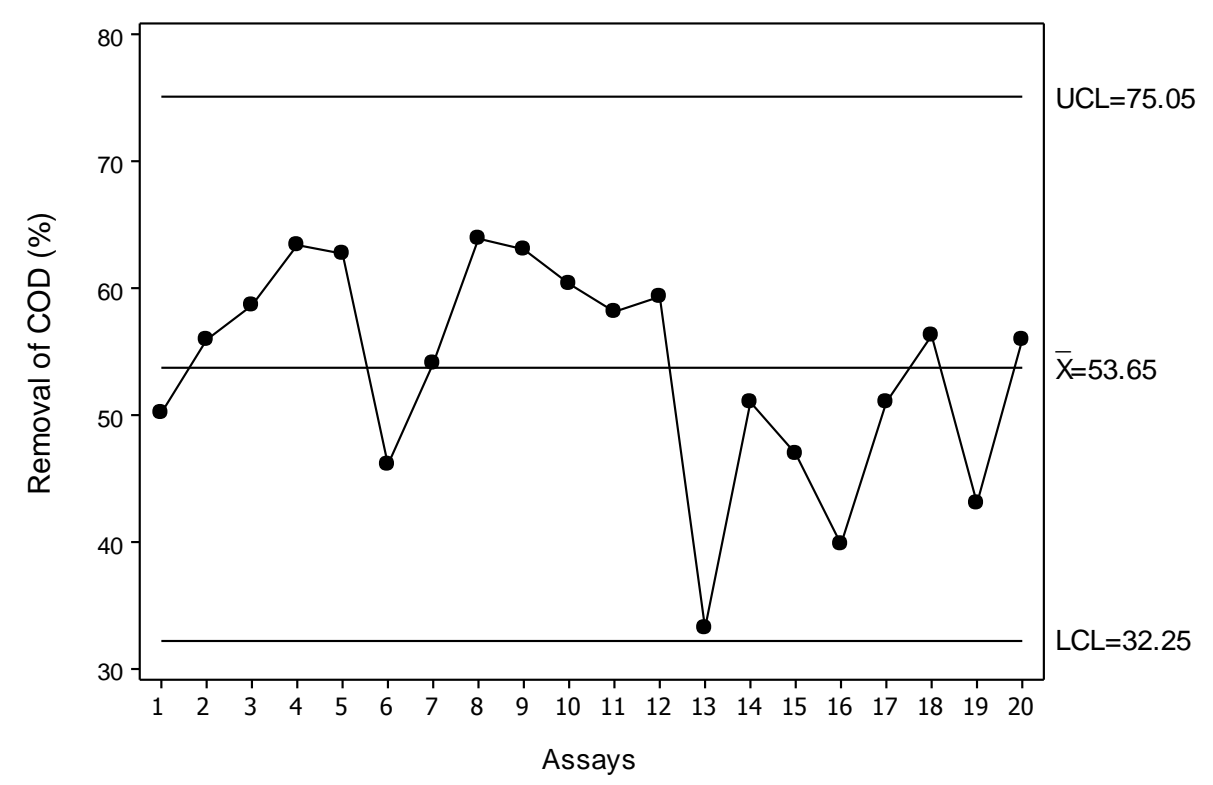

FIGURE 2. Shewhart chart for the removal of COD in the complete process (nitrificationdenitrification).

\section{Kinetics of conversion of nitrogen and removal of organic matter}

Figures 3 and 4 display the nitrogen substrate and organic matter consumption profiles for an SBR with CT of $16 \mathrm{~h}$.

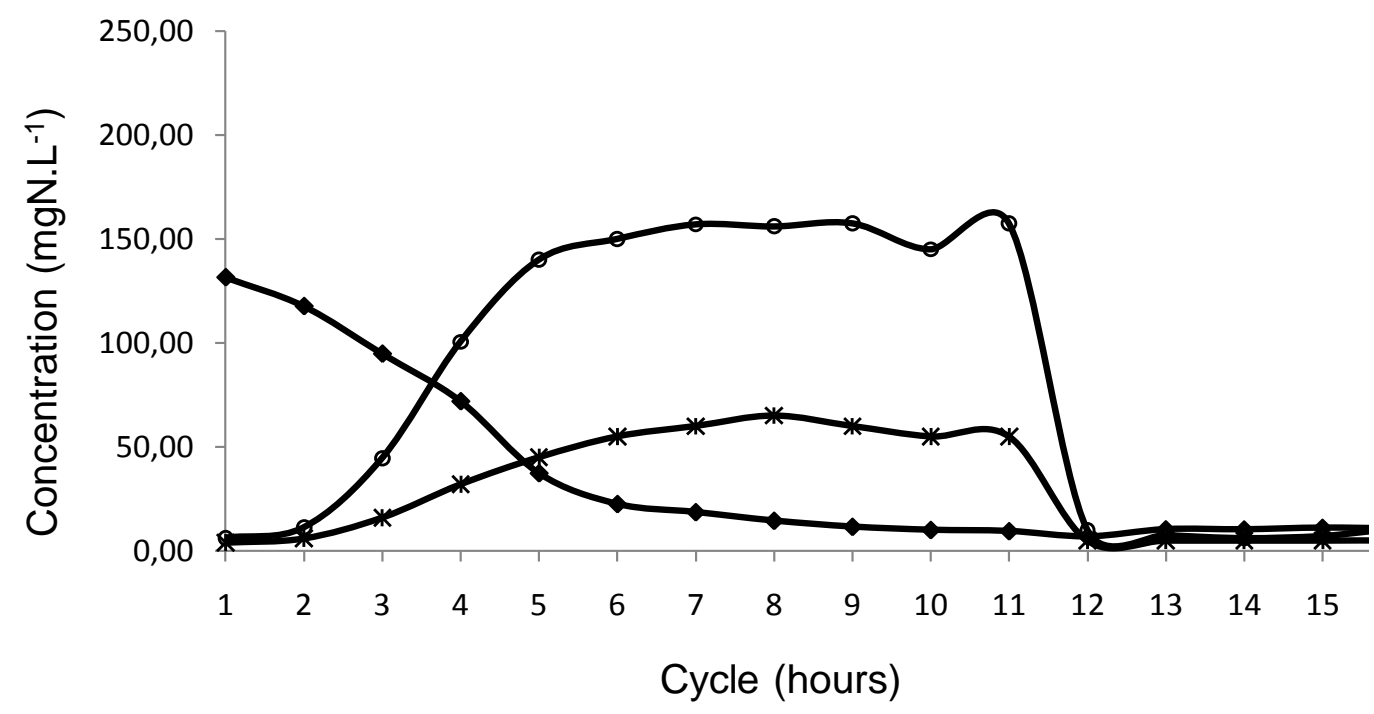

FIGURE 3. Nitrogen substrate consumption $\left(\mathrm{NH}_{4}{ }^{+}-\mathrm{N}, \mathrm{NO}_{2}{ }^{-}-\mathrm{N}\right.$, and $\left.\mathrm{NO}_{3}{ }^{-}-\mathrm{N}\right)$

The analysis of Figure 3 reveals that the consumption of ammoniacal nitrogen $\left(\mathrm{NH}_{4}{ }^{+}-\mathrm{N}\right)$ was more pronounced in the first $7 \mathrm{~h}$ and that it was nearly equimolar. In this same period, there was a gradual increase in the concentration of nitrate $\left(\mathrm{NO}_{3}{ }^{-} \mathrm{N}\right)$, from 6.2 to $157.0 \mathrm{mg} \cdot \mathrm{L}^{-1}$.

The concentration of the nitrogen forms $\left(\mathrm{NO}_{2}{ }^{-} \mathrm{N}\right.$ and $\left.\mathrm{NO}_{3}{ }^{-} \mathrm{N}\right)$ along the anoxic phase decreased for $\mathrm{NO}_{3}^{-}-\mathrm{N}$, from 157.50 to $10.00 \mathrm{mg} \mathrm{L}^{-1}$ in only $1 \mathrm{~h}$ of denitrification, that is, a removal of $93.65 \%$ from 11 to $12 \mathrm{~h}$. The concentration of $\mathrm{NO}_{2}{ }^{-} \mathrm{N}$ also decreased more than $90 \%$ in the same period, indicating a possible reduction of the $\mathrm{Ct}$ of the anoxic phase. 


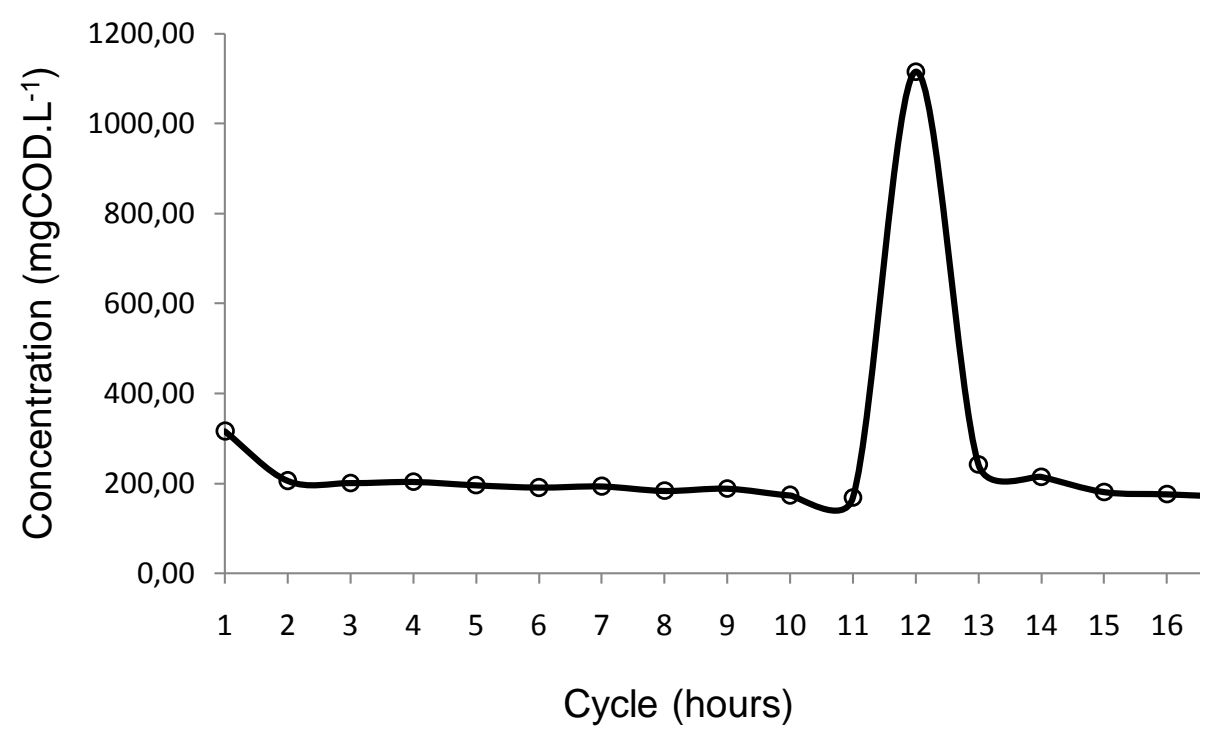

FIGURE 4. Organic matter consumption (COD) profile.

In Figure 4, It can be seen that the concentration of organic matter during the aerobic phase, total CT of $10.15 \mathrm{~h}$, decreased by approximately $50 \%$, falling from 316.25 to $168.74 \mathrm{mg} \mathrm{L}^{-1}$. With the addition of cassava wastewater in the beginning of the anoxic phase to adjust the $\left(\mathrm{COD} / \mathrm{NO}_{2}^{-}-\mathrm{N}\right.$ $\left.+\mathrm{NO}_{3}{ }^{-} \mathrm{N}\right)$ ratio to 6 , the concentration of organic matter reached a mean maximum value of $1115.12 \mathrm{mg} \mathrm{L}^{-1}$, rapidly decreasing to $242.50 \mathrm{mg} \mathrm{L}^{-1}$ in the first hour of anoxic reaction, reaching $157.50 \mathrm{mg} \mathrm{L}^{-1}$ in the end of the anoxic phase, with a total CT of $4.35 \mathrm{~h}$.

An organic matter residue was observed $1 \mathrm{~h}$ after the addition of cassava wastewater with a concentration similar to that found in the end of the aerobic phase.

\section{Kinetic study of the nitrifying activity}

The nitrifying activity was estimated by determining the kinetic parameters based on the fitting of the kinetic models represented by the equations of consumption of the ammoniacal nitrogen substrate (Eq. 2), Nitration (Eq. 3), and nitratation, (Eq. 4). Table 2 displays the mean estimated values of constants $\mathrm{K}_{1}$ and $\mathrm{K}_{2}$.

TABLE 2. Estimated values of $\mathrm{K}_{1}$ and $\mathrm{K}_{2}$.

\begin{tabular}{ccccc}
\hline Nitrification & UNIT & $\mathrm{K}_{1}$ & $\mathrm{~K}_{2}$ & $\mathrm{~K}_{2} / \mathrm{K}_{1}$ \\
\hline CT $10.15 \mathrm{~h}$ & $\min ^{-1}$ & $0.00381 \pm 0.00043$ & $0.00249 \pm 0.00056$ & 0.65 \\
\hline
\end{tabular}

For the conversion of nitrogen, the initial values of ammoniacal nitrogen varied from 121.70 to $147.42 \mathrm{mg} \mathrm{L}^{-1}$. The fitting for the kinetic model of the first-order series reactions described by LEVENSPIEL (2000) gave mean values of $0.00381 \pm 0.00043$ and $0.00249 \pm 0.00056 \mathrm{~min}^{-1}$ for $\mathrm{K}_{1}$ and $\mathrm{K}_{2}$, respectively, with a $\mathrm{K}_{2} / \mathrm{K}_{1}$ ratio of 0.65 , indicating that the conversion of ammoniacal nitrogen to nitrite is not the limiting stage of the process. LEVENSPIEL (2000) found that the more positive this value is in relation to the unit, the smaller the velocity of reaction of formation of the intermediate, which in this case is $\mathrm{NO}_{2}{ }^{-} \mathrm{N}$.

Nitritation was not a limiting stage in relation to the nitration, as was expected; the velocity of formation was greater and the nitrite build-up was small, possibly due to interfering factors such as the occurrence of intermediate reactions, conditions favorable to the development of other microorganisms that only reduce nitrate to nitrite, and the unbalance of the enzyme activity of nitrate and nitrite reductase (MARTIENSSEN \& SCHÖPS, 1999). 
In incomplete nitrification conditions, the nitrite produced during the nitritation by Nitrosomonas becomes an inhibitor of the nitrification process. Nitrite inhibits Nitrobacter in the nitration because of the reaction of this compound with the enzymes involved in its oxidation process (WILD et al., 1995).

In an investigation of the influence of aeration and reaction time on the nitrification process of the effluent of a Fish slaughterhouse effluent using an SBR with immobilized biomass in workbench scale, ZENATTI (2007) estimated the kinetic parameters of nitrification, obtaining $\mathrm{K}_{1}$ and $\mathrm{K}_{2}$ mean values of $0.00300 \pm 0.00030$ and $0.00298 \pm 0.00024 \mathrm{~min}^{-1}$, respectively, with a $\mathrm{K}_{2} / \mathrm{K}_{1}$ ratio of approximately 1 , when the reactor was operated with air flow of $6 \mathrm{~L}^{-\mathrm{min}^{-1}}$ and with an effluent volume of $2.5 \mathrm{~L}$ and reaction time of $12 \mathrm{~h}$. These values are similar to the present ones; however, for a higher air flow.

FAZOLO et al. (2001) evaluated the performance of an aerobic fixed bed reactor in workbench scale in the post-treatment of anaerobic sewage effluent. They found mean values of kinetic constants, $\mathrm{K}_{1}$ and $\mathrm{K}_{2}$, of $0.00419 \pm 0.00095$ and $0.1104 \pm 0.01105 \mathrm{~min}^{-1}$, respectively, operating with air flows varying from 2 to $15 \mathrm{~L} \mathrm{~min}^{-1}$, for an effluent volume of $10 \mathrm{~L}$ in $4.0,6.0$, and $8.0 \mathrm{~h}$, values which are higher than those of the present study in both stages of the nitrification reaction (nitritation and nitration). This is possibly due to factors such as the reactor configuration, the aeration system utilized, the immobilization of the biomass, and others.

For WEF et al. (2005), several factors, such as the temperature, the pH, oxygen concentration, the type of substrate, and the presence of inhibiting substances affect the growth of microorganisms. Therefore, they influence the velocity of consumption of the substrate and the formation of products of the biochemical reactions.

\section{CONCLUSIONS}

The study of the stability of an SBR using Shewhart charts applied to the global removal of inorganic nitrogen and organic matter revealed that the process is under statistical control. The removal of total inorganic nitrogen $\left(\mathrm{NH}_{4}{ }^{+}-\mathrm{N}+\mathrm{NO}_{2}{ }^{-}-\mathrm{N}+\mathrm{NO}_{3}{ }^{-}-\mathrm{N}\right)$ reached mean values of $84.32 \pm 1.59 \%$ (C.V. $=1.89 \%$ ) and removal of organic matter (CDO) of $53.65 \pm 8.48 \%$ (C.V. $=15.81 \%$ ) in the complete process (nitrification-denitrification) during the 20 cycles that were evaluated.

The nitrifying activity estimated from the determination of the first-order kinetic parameters had mean values of $K_{1}$ and $K_{2}$ of $0.00381 \pm 0.00043$ and $0.00381 \pm 0.00043 \mathrm{~min}^{-1}$, respectively. The evaluation of the kinetic behavior of the removal of organic matter, and mainly the conversion of nitrogen, indicated a possible reduction of $\mathrm{CT}$ in the anoxic phase, since removal rates of $\mathrm{NO}_{2}^{-}-\mathrm{N}$ and $\mathrm{NO}_{3}{ }^{-} \mathrm{N}$ higher than $90 \%$ were obtained with only $1 \mathrm{~h}$ of denitrification.

\section{ACKNOWLEDGEMENTS}

We thank CNPq for financial support.

\section{REFERENCES}

AKIN, B.S.; UGURLU, A. Monitoring and control of biological nutrient removal in a sequencing batch reactor. Process Biochemistry, London, v.40, n.8, p.2873-2878, 2005.

ANDRADE, L.; KUMMER, A.C.B.; FAZOLO, A.; DAMASCENO, S.; HASAN, S.D. Influência de nitrogênio amoniacal e vazão de ar no processo de nitrificação, etapa de tratamento de efluente de abatedouro de peixe. Engenharia Agrícola, Jaboticabal, v.30, n.1, p.160-167, 2010.

APHA. AMERICAN PUBLIC HEALTH ASSOCIATION. Standard methods for the examination of water and wastewater. $20^{\text {nd }}$ ed. Washington, 1998, $1.193 \mathrm{p}$.

BAE, W.; BAEK, S.; CHUNG, J.; LEE, Y. Optimal operational factors for nitrite accumulation in batch reactors. Biodegradation. Dordrecht, v.12, n.5, p.359-366, 2002. 
CARVALLO, L.; POIRRIER, P.; CHAMY, R. Nitrifying activity monitoring and kinetic parameters determination in a biofilm airlift reactor by respirometry. Biotechnology Letters, Dordrecht, v.24, n.24, p.2063-2066, 2002.

FAZOLO, A.; VIEIRA, G.T.L.; FORESTI, E.; ZAIAT, M. Estimativa dos parâmetros cinéticos e de transferência de massa em um reator aeróbio de leito fixo utilizado no pós-tratamento de efluente anaeróbio. In: Chernicharo, C. A. de L. (Org.). Pós-tratamento de reatores anaeróbios. Belo Horizonte: Segrac Editora e Gráfica, 2001. v.2.

FERREIRA, E.S. Cinética química e fundamentos dos processos de nitrificação e denitrificação biológica. In: CONGRESSO INTERAMERICANO DE ENGENHARIA SANITÁRIA E AMBIENTAL, 27., 2000, Porto Alegre. Anais... Porto Alegre: Universidade Federal do Rio Grande do Sul, 2000.

FIGUEROA, L.A.; SILVERSTEIN, J. The effect of particulate organic matter on biofilm nitrification. Water Environment Research, Alexandria, v.64, n.5, p.728-733, 1992.

FONTENOT, Q.; BONVILLAIN, C.; KILGEN, M.; BOOPATHY, R. Effects of temperature, salinity, and carbon: nitrogen ratio on sequencing batch reactor treating shrimp aquaculture wastewater. Bioresource Technology, Essex, n.98, p.1700-1703, 2007.

GRADY, C.P.L.; DAIGGER, G.T.; LIM, H.C. Biological wastewater treatment. $2^{\text {nd }}$ ed. New York: Marcel Dekker, 1999. 1076 p.

GROMMEN, R.; DAUW, L.; VERSTRAETE, W. Elevated salinity selects for a less diverse ammonia-oxidizing population in aquarium biofilters. FEMS Microbiology Ecology, Amsterdam, v.52, n.1, p.1-11, 2005.

GRUNDITZ, C.; DALHAMMAR, G. Development of nitrification inhibition assays using pure cultures of Nitrosomonas and Nitrobacter. Water Research, New York, v.35, n.2, p.433-440, 2001.

HAMMER, M.J.; HAMMER, M.J. Water and Wastewater Technology. $6^{\text {th }}$ ed. New Jersey: Prentice Hall International, 2007.

JANG, J.D.; BARFORD, J.P.; LINDAWATI; RENNEBERG, R. Application of biochemical oxygen demand (BOD) biosensor for optimization of biological carbon and nitrogen removal from synthetic wastewater in a sequencing batch reactor system. Biosensors and Bioelectronics, Essex, v.19, p.805-812, 2004.

JULIASTUTI, S.R.; BAEYENS, J.; CREEMERS, C.; BIXIO B.; LODEWYCKX, E. The inhibitory effects of heavy metals and organic compounds on the net maximum specific growth rate of the autotrophic biomass in activated sludge. Journal of Hazardous Materials, Amsterdam, v.100, n.1, p.271-283, 2003.

KUMMER, A.C.B. Desnitrificação de efluente de abatedouro de tilápia utilizando manipueira como fonte de carbono. 2008. 53 f. Dissertação (Mestrado em Engenharia Agrícola) - Universidade Estadual do Oeste do Paraná, Cascavel, 2008.

LEVENSPIEL, O. Engenharia das reações químicas. São Paulo: Editora Edgard Blücher, 2000. $584 \mathrm{p}$.

LI, B.; IRVIN, S. The comparison of alkalinity and ORP as indicators for nitrification as denitrification in a sequencing bacth reactor (SBR). Biochemical Engineering Journal, Amsterdam, n.34, p.248-255, 2007.

MARTIENSSEN, M.; SCHÖPS, R. Population dynamics of denitrifying bacteria in a model biocommunity. Water Research, New York, v.33, n.3, p.639-646, 1999.

METCALF \& EDDY. Wastewwater engineering: treatment, disposal and reuse. 3.ed. New York: McGraw Hill, 2003. 1335 p. 
MONTGOMERY, D.C. Introdução ao controle estatístico da qualidade. 4.ed. Rio de Janeiro: LTC, 2004. 513 p.

SEIXO, J.; VARELA M. H.; COUTINHO, J.A.P.; COELHO, M.A.Z. Influence of C/N ratio on autotrophic biomass development in a sequencing batch reactor. Biochemical Engineering Journal, Amsterdam, n.21, p.131-139, 2004.

ZENATTI, D.C. Avaliação da nitrificação de efluente de abatedouro de tilápia em reator em batelada sequencial com biomassa imobilizada. 2007. 90 f. Dissertação (Mestrado em Engenharia Agrícola) - Universidade Estadual do Oeste do Paraná, Cascavel, 2007.

UYGUR, A.; KARGI, F. Salt inhibition on biological nutrient removal from saline wastewater in a sequencing batch reactor. Enzyme and Microbial Technology, New York, v.34, n.3-4, p.313-318, 2004.

WANNER, J. Use of the routine biological analysis to check the performance of sewage treatment plants. In: INTERNATIONAL SYMPOSIUM BIOLOGICAL APPROACH TO SEWAGE

TREATMENT PROCESS: CURRENT STATUS AND PERSPECTIVES, 1991, Perugia. Anais... Perudia: ed. Paolo Madoni, 1991. p.199-210.

WERKEMA, M.C.C. Ferramentas estatísticas básicas para o gerenciamento de processos. Belo Horizonte: Fundação Cristiano Ottoni, Escola de Engenharia da UFMG, 1995. 404 p.

Water Environment Federation - WEF; American Society of Civil Engineers - ASCE;

Environmental Water Resources Institute - EWRI. Biological nutrient removal (BNR) operation in wastewater treatment plants (Asce Manual and Reports on Engineering Practice). New York:

McGraw-Hill, 2005.

WIESMANN, U.; CHOI, I.S.; DOMBROWSK, E.M. Fundamentals of biological wastewater treatment. Weinheim: WILEY-VCH Verlang GmbH \& Co KGaA, 2007. 362 p.

WILD, D.; SCHULTHESS, R.; GUJER, W. Structured modeling of denitrification intermediates. Water Science and Technology, Oxford, v.31, n.2, p.45-54, 1995. 